\title{
FORMATION AND USE OF FINANCIAL POTENTIAL OF INVESTMENT ACTIVITY OF SMALL ENTERPRISES
}

\author{
Ruslan Yurkiv ${ }^{1}$
}

\begin{abstract}
The purpose of the paper is to study the processes of formation and use of financial potential of investment activity of small enterprises. The subject of research is the patterns of formation of financial potential of investment activity of small enterprises. Methodology included structural and systems analysis, as well as the theory of optimal control. In addition, methods of economic and statistical analysis were used. The main results of the study include the definition of the essence and selection of types of the financial potential of investment activity of enterprises. It is found that the financial potential of investment activity of the enterprise is its ability to attract financial resources to ensure this activity. The available, aggregate, and long-term financial potentials of investment activity are defined and characterized. The possibility of distinguishing the general, effective and optimal varieties of this potential are also noted. It is shown that the aggregate financial potential of investment activity of the enterprise, in addition to the available potential, also includes the available reserve for the growth of the financial potential of investment activity due to the implementation of measures that do not require investment. It is proven that the financial potential of investment activity of small enterprises is at the intersection of two other types of their economic opportunities: investment potential and the potential of the flow of the financial resources to finance investment activity of enterprises. The generalized model of the course of processes of formation and use of the financial potential of investment activity of small enterprises is constructed and analyzed. A number of indicators for assessing the level of use of the financial potential of investment activity of small enterprises are proposed. In particular, these indicators include the share of the actual volume of realization of the available financial potential of investment activity of enterprises in the amount of the potential, the share of the available financial potential of investment activity of enterprises in the value of their investment potential, the share of the actual volume of realization of the available financial potential of investment activity of enterprises in the value of their investment potential. The third indicator is the product of the previous two. The level of investment activity and use of the available financial potential of investment activity of fifty Ukrainian small enterprises is studied. It is established that the largest share includes enterprises with a low and satisfactory level of investment activity. At the same time, the average level of realization of the available financial potential of investment activity of enterprises increases with the growth of investment activity. The practical significance of the results in the work of small enterprises will allow to identify and implement untapped opportunities for growth in the financial potential of investment activity of these enterprises. Also, these results make it possible to establish the level of actual realization of this potential and identify areas for increasing this level, which is especially relevant in the context of the COVID-19 pandemic.
\end{abstract}

Key words: financing, investment, potential, enterprise, model, indicator.

JEL Classification: C10, G30, M21

\section{Introduction}

One of the conditions for the successful operation of enterprises is to ensure their sustainable economic development, which is a gradual and steady increase in the value of financial and economic results of economic activity. However, as the experience of this activity shows, many enterprises, especially small ones, face barriers to their sustainable economic development
(Jaramillo et al., 2019; Tambunan, 2019). One of the main barriers is the lack of adequate capacity of enterprises for their sustainable economic development (Yemelyanov et al., 2018; Yemelyanov et al., 2016). In turn, an important component of this potential is the financial potential of investment activity of enterprises.

Nowadays, many small businesses around the world face the problem of insufficient capacity

\footnotetext{
Corresponding author:

${ }^{1}$ Ivan Franko National University of Lviv, Ukraine.

E-mail: nataliya.halevych@gmail.com

ORCID: https://orcid.org/0000-0001-9016-6634
} 
of the available financial potential (Olugbenga et al., 2017; Upadhyaya, 2011), which is reflected, among other things, in the difficulty of attracting borrowed financial resources (Akinleye et al., 2019; Rostamkalaei et al., 2016; Yang, 2018). In turn, this reduces the ability of enterprises to benefit from financial leverage (Adenugba et al., 2016; Hoque, 2017; Iqbal et al., 2018; Javed et al., 2015).

Accordingly, the process of forming the financial potential of investment activity of small enterprises should include, first of all, the removal of barriers to external financing of business activity (Bhalli et al., 2017; Bondinuba, 2012; Krasniqi, 2010). The presence of a significant number of such barriers determines the complexity of the mechanisms of formation and use of the financial potential of investment activity of enterprises. Nowadays, the functioning of these mechanisms is not fully studied in the scientific literature, so there is a need for further study. In this case, the purpose of the paper is to study the processes of formation and use of the financial potential of investment activity of small enterprises.

\section{The essence and types of the financial potential of investment activity of enterprises}

The financial potential of investment activity of the enterprise is its ability to attract financial resources to ensure this activity. We should note the existence of varieties of this potential.

In particular, it is expedient to allocate the available, aggregate, and long-term financial potential of investment activity. The available financial potential of investment activity of the enterprise characterizes its current ability to attract financial resources to support this activity. At the same time, the aggregate financial potential of investment activity of the enterprise, in addition to the available potential, also includes the existing reserve for the growth of the available financial potential of investment activity due to the implementation of measures that do not require investment. In particular, such measures may include improving the competence of managers of the enterprise in the matters of formation of its financial potential and improving the information support of the process of making financial and investment decisions at the enterprise.

After all, the long-term financial potential of investment activity of the enterprise is its ability to attract financial resources to ensure this activity in the future. The basic factors that influence the formation of the long-term financial potential of investment activity of the business entity are the improvement of the competence of managers of the enterprise, information support of their activity and conditions of operation of the enterprise in the future. Thus, the long-term financial potential of investment activity of the enterprise will contain two main components: the available financial potential of this activity and the expected change of this potential in the future. In turn, the available financial potential of the enterprise's investment activity will include its used and unused parts.

It is also appropriate to highlight the general, effective, and optimal financial potential of investment activity of the enterprise. The aggregate financial potential of investment activity of the enterprise can be estimated by the total amount of financial resources that can be attracted by the enterprise. The effective financial potential of investment activity can be estimated by the maximum amount of financial resources that the company can attract while ensuring the growth of financial results of economic activity. Thus, the general financial potential of investment activity of the enterprise contains effective and excess potential. Finally, the optimal financial potential of investment activity of the enterprise can be estimated by such amount of financial resources that the enterprise can attract while ensuring the maximum growth of financial results of its economic activity.

\section{Modelling of the processes of formation and use of the financial potential of investment activity of small enterprises}

The main feature of the formation of the financial potential of investment activity of small businesses lies in the fact that this type of the aggregate economic potential of enterprises is at the intersection of two other types of their economic opportunities, namely investment potential and the potential for financial resources to finance investment activity of firms (Figure 1).

In this case, the investment potential of enterprises should be understood as their ability to conduct effective investment activity over time. This will be measured by the optimal amount of investment activity of business entities according to a certain criterion (maximum profit, maximum market value of enterprises, etc.), i.e., the optimal amount of investment that is appropriate to invest in their development.

The potential of the enterprise to receive financial resources to finance its investment activity should be interpreted as the ability of the enterprise to receive a certain amount of financial resources from all possible sources for some time to ensure investment activity. This will be measured by the optimal amount of financial resources for financing investment activity of the enterprise according to a certain criterion.

Under such conditions, the value of the financial potential of investment activity of business entities will be defined as the minimum of the values of the two types of their economic potential described above, namely investment potential and the potential 


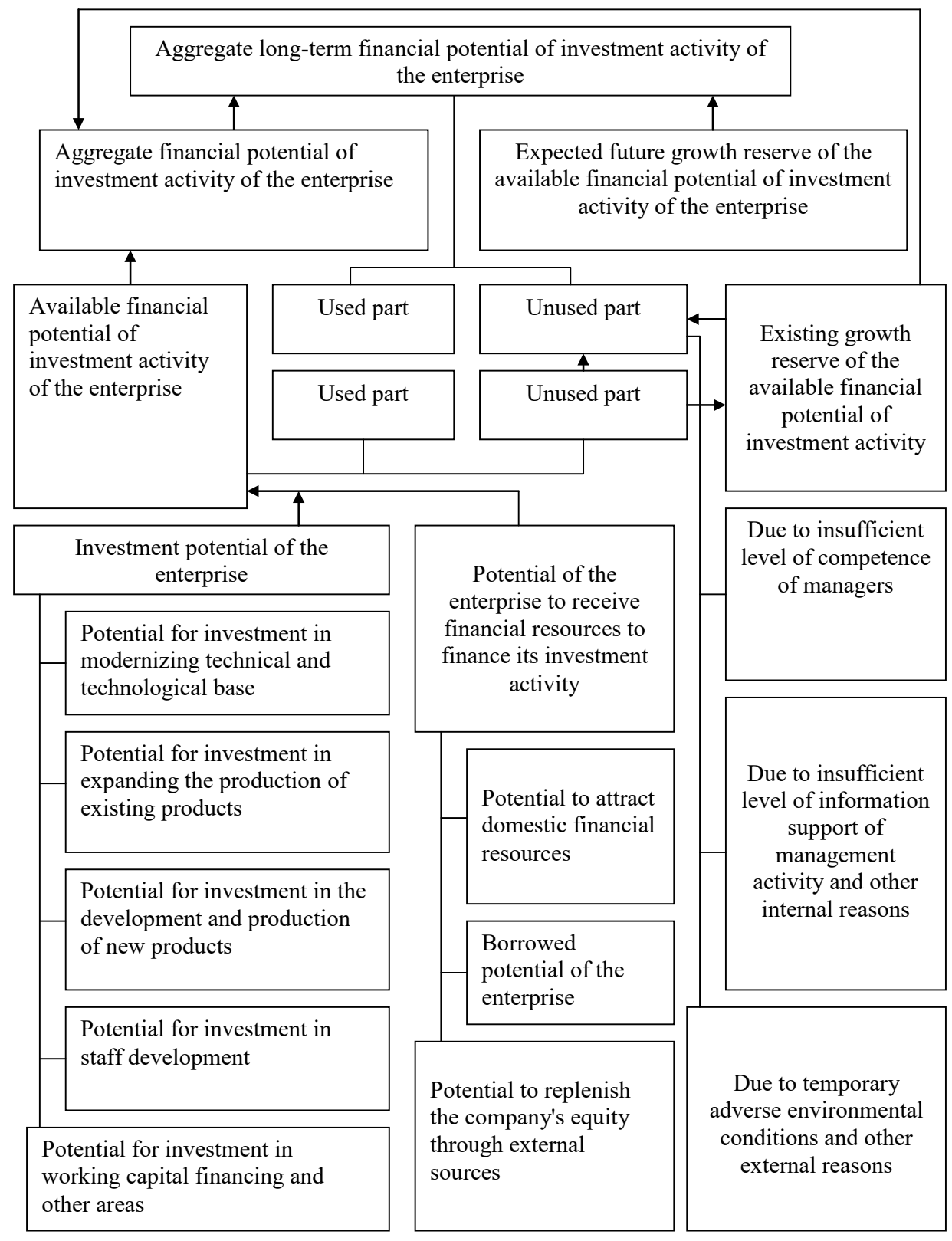

Figure 1. Generalized model of formation and use of the financial potential of investment activity of small enterprises

Source: developed by the author

of financial resources for enterprises to finance their investment activity.

We should also note the fact that the processes of optimizing the volume of investment activity of the enterprise and the amount of financial resources that the enterprise receives in order to carry out this activity may be interlinked. The value of the optimal amount of investment in the development of the enterprise, among other factors, is influenced by the price of attracting these investments from certain sources of funds. On the other hand, the price of attraction may grow with increasing investment needs.

In addition to the above, the peculiarities of the formation of the financial potential of investment activity of small enterprises should include the presence of this type of economic potential of enterprises of a rather complex structure, its hierarchical structure and the existence of a significant number of factors that directly or indirectly affect the financial potential of investment activity of the enterprises.

In particular, both the investment potential and the potential of the enterprise to receive financial resources to finance its investment activity have several components and varieties. The main components of the investment potential of economic entities include the potential of investing in updating the technical and technological base of the enterprise, expanding the production of existing products, development and 
production of new products, staff training, working capital and more.

Regarding the potential of the enterprise to receive financial resources to finance its investment activity, it is advisable to distinguish three main components of it, namely - the potential to attract internal financial resources of the enterprise, the potential to replenish equity from external sources and borrowed potential.

\section{Features of formation and evaluation of the borrowed potential of a small enterprise}

The borrowed potential plays a particularly important role in ensuring the investment process in small enterprises, as these enterprises are often characterized by rather limited amounts of internal sources of financing for investment projects that are planned to be implemented. Under such conditions, borrowed funds can be a powerful source of economic growth for small businesses, provide a significant increase. At the same time, the use of borrowings to finance investment activity of small businesses can be associated with a significant level of investment risk and even lead to a financial crisis in enterprises with the threat of their further bankruptcy. With this in mind, the implementation of investment projects by small enterprises at the expense of borrowed funds should provide for a preliminary evaluation of the borrowed potential of investment activity of these enterprises.

It should be noted that the borrowed potential of investment activity of enterprises characterizes their ability to use certain amounts of borrowed financing of this activity while ensuring appropriate levels of effectiveness of this activity and financial stability of the enterprises.

Evaluation of the borrowed potential of investment activity of the enterprise requires the implementation of the following main phases:

1) creating a block of input information necessary for such evaluation (in particular, information on the available volume and structure of borrowed capital of the enterprise, the expected amount of earnings before interest and taxes, indicators of investment projects considered by the enterprise for their possible implementation, etc);

2) predicting the flow of earnings of the enterprise before interest and taxes in the case of the implementation of its planned investment projects (such predictions should be performed on a moderately pessimistic estimate of the expected profit);

3) establishing the maximum possible amount of borrowed financing of investment activity of the enterprise, at which the expected flow of future profits of the enterprise will allow to pay interest on borrowings timely and in full and repay their principal amount;
4) evaluating the predictive economic efficiency of borrowed financing of investment activity of the enterprises.

The use of the described sequence of assessing the borrowed potential of investment activity of small enterprises in the practice of their activity will increase the degree of validity of financial and investment decisions made by the owners of these enterprises.

\section{Indicators for evaluating the level of use of the financial potential of investment activity of small enterprises}

The value of the available financial potential of investment activity of small enterprises is often less than the value of their investment potential. This is due, in particular, to the limited capacity of domestic sources of funds and the difficulties associated with obtaining bank borrowings by enterprises. Under such conditions, indicators for evaluating the level of use of the financial potential of investment activity of small enterprises can be divided into two groups: general and partial. The general indicators, first of all, should include the following:

1) the share of the actual volume of realization of the available financial potential of investment activity of enterprises in the amount of this potential;

2) the share of the available financial potential of investment activity of enterprises in the amount of their investment potential;

3) the share of the actual volume of realization of the available financial potential of investment activity of enterprises in the amount of their investment potential. The third indicator is the product of the previous two.

With regard to partial indicators for evaluating the level of use of the financial potential of investment activity of small enterprises, these indicators are similar in design to general indicators but are calculated by individual areas of investment or by certain sources of financial support for investment activity of business entities. In particular, it is possible to allocate shares of: 1) the actual volume of realization of the available potential of attraction of internal financial resources of the enterprise for carrying out its investment activity in the total value of this potential; 2) the actual volume of realization of the available potential of replenishment of own capital at the expense of external sources of financing of the enterprise for carrying out its investment activity in the general size of this potential; 3) the actual volume of realization of the available potential of the enterprise to obtain borrowings for the purpose of its investment activity in the total amount of this potential. Also, the indicators of the impact of such a level on each of the components of this potential on the overall degree of its use should be included in the partial indicators for evaluating the level of use of 
the financial potential of investment activity of small enterprises.

\section{Empirical analysis: the case of small enterprises in Ukraine}

In order to evaluate the level of use of the financial potential of investment activity of small enterprises in Ukraine, fifty enterprises were selected. These enterprises belonged to two types of economic activity, namely - trade and provision of household services to the population. At the same time, according to the level of investment activity, all enterprises were divided into four groups as follows: enterprises with a low level of this activity (during 2019, the growth rate of total assets did not exceed 1.05); enterprises with a satisfactory level of investment activity (during 2019 , the growth rate of total assets was in the range from 1.05 to 1.2 ); enterprises with a sufficiently high level of investment activity (during 2019, the growth rate of total assets ranged from 1.2 to 1.4 ); enterprises with a high level of investment activity (during 2019, the growth rate of total assets exceeded 1.4).

Results of evaluation of investment activity and level of use of the financial potential of investment activity of small enterprises of Ukraine, which trade and provide household services, are presented in Table 1 and Table 2, respectively.

According to the data given in Tables 1 and 2, the largest share for both studied economic activity is of enterprises with low and satisfactory level of investment activity. At the same time, with the growth of investment activity, the average level of use of the available financial potential of investment activity of enterprises increases (this conclusion is confirmed by the results of the analysis of variance). A study of the factors that led to incomplete use of the available financial potential of investment activity of enterprises has been also conducted (the possibility of simultaneous action of each of the factors has been considered). The study confirms that the reasons for this phenomenon are, first of all, the lack of the

Table 1

Results of evaluation of investment activity and level of use of the financial potential of investment activity of small Ukrainian enterprises in trade

\begin{tabular}{|c|c|c|c|c|}
\hline \multirow{2}{*}{ Titles of indicators } & \multicolumn{4}{|c|}{$\begin{array}{l}\text { The value of indicators by groups of enterprises } \\
\text { according to the level of their investment activity }\end{array}$} \\
\hline & Low level & $\begin{array}{l}\text { Satisfactory } \\
\text { level }\end{array}$ & $\begin{array}{l}\text { Sufficiently } \\
\text { high level }\end{array}$ & $\begin{array}{l}\text { High } \\
\text { level }\end{array}$ \\
\hline 1. The number of enterprises in the group & 7 & 9 & 6 & 4 \\
\hline $\begin{array}{l}\text { 2. The share of enterprises of the corresponding group in the total number } \\
\text { of enterprises, } \%\end{array}$ & 26.92 & 34.62 & 23.08 & 15.38 \\
\hline 3. The average growth rate of total assets during 2019 according to the balance sheets, times & 1.02 & 1.13 & 1.27 & 1.48 \\
\hline $\begin{array}{l}\text { 4. The average level of use of the available financial potential of investment activity in } \\
2019 \text {, the share of the unit }\end{array}$ & 0.28 & 0.47 & 0.68 & 0.80 \\
\hline \multicolumn{5}{|l|}{$\begin{array}{l}\text { 5. The share of enterprises in the total number of enterprises of the relevant group, } \\
\text { in which the main reason for incomplete use of the available financial potential of } \\
\text { investment activity in } 2019 \text { is: }\end{array}$} \\
\hline 5.1. Insufficient competence in evaluating the investment potential of the enterprise, $\%$ & 60.00 & 44.44 & 75.00 & 50.00 \\
\hline $\begin{array}{l}\text { 5.2. Insufficient competence in attracting financial resources to finance investment } \\
\text { activity, \% }\end{array}$ & 80.00 & 66.67 & 37.50 & 25.00 \\
\hline
\end{tabular}

Table 2

Results of evaluation of investment activity and level of use of the financial potential of investment activity of small Ukrainian enterprises in providing household services to the population

\begin{tabular}{|c|c|c|c|c|}
\hline \multirow{2}{*}{ Titles of indicators } & \multicolumn{4}{|c|}{$\begin{array}{l}\text { The value of indicators by groups of enterprises } \\
\text { according to the level of their investment activity }\end{array}$} \\
\hline & Low level & $\begin{array}{l}\text { Satisfactory } \\
\text { level }\end{array}$ & $\begin{array}{c}\text { Sufficiently } \\
\text { high level }\end{array}$ & $\begin{array}{l}\text { High } \\
\text { level }\end{array}$ \\
\hline 1. The number of enterprises in the group & 7 & 9 & 5 & 3 \\
\hline 2. The share of enterprises of the corresponding group in the total number of enterprises, $\%$ & 29.17 & 37.50 & 20.83 & 12.50 \\
\hline 3. The average growth rate of total assets during 2019 according to the balance sheets, times & 1.01 & 1.17 & 1.30 & 1.47 \\
\hline $\begin{array}{l}\text { 4. The average level of use of the available financial potential of investment activity in } 2019 \text {, } \\
\text { the share of the unit }\end{array}$ & 0.35 & 0.53 & 0.66 & 0.85 \\
\hline \multicolumn{5}{|l|}{$\begin{array}{l}\text { 5. The share of enterprises in the total number of enterprises of the relevant group, in which } \\
\text { the main reason for incomplete use of the available financial potential of investment activity } \\
\text { in } 2019 \text { is: }\end{array}$} \\
\hline 5.1. Insufficient competence in evaluating the investment potential of the enterprise, $\%$ & 57.14 & 55.56 & 80.00 & 66.67 \\
\hline 5.2. Insufficient competence in attracting financial resources to finance investment activity, \% & 71.43 & 66.67 & 60.00 & 33.33 \\
\hline
\end{tabular}


appropriate level of competence in assessing the investment potential of the enterprise and attracting financial resources to finance investment activity in managers of the enterprises under study.

\section{Conclusions}

The mechanism of formation of the financial potential of investment activity of the enterprises, in particular small businesses, is complex and multifaceted. Therefore, the implementation of this mechanism in the practice of business entities requires the preliminary selection of all its main components and the establishment of relationships between them. In particular, it is expedient to allocate the available, aggregate and long-term financial potential of investment activity. The general, effective and optimal varieties of this potential are distinguished.

The main feature of the formation of the financial potential of investment activity of the small businesses lies in the fact that this potential is at the intersection of two other types of their economic opportunities, namely - investment potential and the potential for financial resources to finance investment activity of firms. In particular, both the investment potential and the potential of the enterprise to receive financial resources to finance its investment activity have several components and varieties. The main components of the investment potential of economic entities include the potential of investing in: modernizing the technical and technological base of the enterprise, expanding the production of existing products, development and production of new products, staff development, working capital and more.

The use of the results of the study in the practice of small enterprises will allow their owners to identify and implement reserves to increase the financial potential of investment activity. Also, the results obtained in the study provide an opportunity to assess the level of use of the financial potential of investment activity of small businesses and identify areas for improvement of this level, which is especially relevant in the pandemic COVID-19.

The evaluation of the impact of the capital structure of small enterprises on the value of the financial potential of their investment activity requires further research.

\section{References:}

Adenugba, A. A., Ige, A. A., \& Kesinro, O. R. (2016). Financial leverage and firms' value: A study of selected firms in Nigeria. Eur. J. Res. Reflect. Manag. Sci., vol. 4, pp. 14-32.

Akinleye, G. T., \& Olarewaju, O. O. (2019). Credit Management and Profitability Growth in Nigerian Manufacturing Firms. Acta Univ. Danub. Oecon., vol. 15, pp. 445-456.

Bhalli, M., Hashmi, S., \& Majeed, A. (2017). Impact of Credit Constraints on Firms Growth: A Case Study of Manufacturing Sector of Pakistan. J. Quant. Method., vol. 1, pp. 4-40.

Bondinuba, F. (2012). Exploring the Challenges and Barriers in Accessing Financial Facilities by Small and Medium Construction Firms in Ghana. Civ. Environ. Res., vol. 2, pp. 25-35.

Hoque, M. A. (2017). Impact of financial leverage on financial performance: Evidence from textile sector of Bangladesh. IIUC Bus. Rev., vol. 6, pp. 75-84.

Iqbal, U., \& Usman, M. (2018). Impact of Financial Leverage on Firm Performance: Textile Composite Companies of Pakistan. SEISENSE J. Manag., vol. 1, pp. 70-78.

Jaramillo, J., Sossa, J. W. Z., \& Mendoza, J. L. O. (2019). Barriers to sustainability for small and medium enterprises in the framework of sustainable development - Literature review. Bus. Strategy Environ, vol. 28, pp. 512-524.

Javed, Z. H., Rao, H. H., Akram, B., \& Nazir, M. F. (2015). Effect of Financial Leverage on Performance of the Firms: Empirical Evidence from Pakistan. SPOUDAI J. Econ. Bus., vol. 65, pp. 87-95.

Krasniqi, B. A. (2010). Are small firms really credit constrained? Empirical evidence from Kosova. Int. Entrep. Manag. J., vol. 6, pp. 459-479.

Olugbenga, S., \& Mashigo, P. (2017). The impact of microfinance on microenterprises. Invest. Manag. Financ. Innov., vol. 14, pp. 82-92.

Rostamkalaei, A., \& Freel, M. S. (2016). The cost of growth: Small firms and the pricing of bank loans. Small Bus. Econ., vol. 46, pp. 255-272.

Tambunan, T. (2019). Recent evidence of the development of micro, small and medium enterprises in Indonesia. J. Glob. Entrep. Res., vol. 9(18), pp. 1-15.

Upadhyaya, A. S. (2011). Micro Finance in Sustainable Development: A Descriptive Study on Indian Experience. J. Econ. Dev., vol. 13, pp. $72-88$.

Yang, W. (2018). Empirical Study on Effect of Credit Constraints on Productivity of Firms in Growth Enterprise Market of China. J. Financ. Econ., vol. 6, pp. 173-177.

Yemelyanov, O., Kurylo, O., \& Petrushka, T. (2018). Methodological principles of evaluating economic potential of industrial enterprise sustainable development. Scientific Bulletin of Polissia, vol. 2(14), pp. 141-149.

Yemelyanov, O., Symak, A., \& Zarutska, O. (2016). Modelling the process of forming the potential of economic development of an industrial enterprise. Periodyk naukowy Akademii Polonijnej, Czestochowa, Akademia Polonijna $w$ Czestochowie, vol. 3, pp. 128-137. 